\title{
Dietary intake of pregnant women and its effect on the birth weight of newborns in rural area of Uttar Pradesh, India
}

\author{
Krishna Kumar Sahu1, M.Z. Idris², Monika Agarwal2, S.K. Singh², M.K. Manar² \\ ${ }^{1}$ Department of Community Medicine, Shrinivas Institute of Medical Sciences \& Research Centre, Mukka, Surathkhal, ${ }^{2}$ Department of \\ Community Medicine and Public Health, K.G. Medical University, UP, Lucknow, India
}

\section{A B S T R A C T}

Background: Nutritional deficiency during pregnancy in rural India is common. The nutritional requirements during pregnancy are increased and on the other hand the dietary intake decreases because of symptoms related to pregnancy. This adversely affects the weight of newborn. In developing countries low birth weight is major problem. So this study concern to determine the nutritional status of pregnant women and its effect on birth weight of newborn. Methods: A cross section descriptive study was conducted from Oct 2011 to May 2012 at Sarojni Nagar PHC, Lucknow, Uttar Pradesh over 323 pregnant women. They were interviewed regarding their dietary intake (on the basis of 24 hours recall method) during pregnancy. Of these 323 pregnant women, 291 could be followed up and amongst these 287 pregnant women delivered a live baby. The birth weight was measured immediate after birth. Results: In this study mean energy, protein, iron and calcium intake during pregnancy were $2013.3 \pm 327.6 \mathrm{cal} /$ day, $57.8 \pm 11.4 \mathrm{gm} / \mathrm{day}, 30.15 \pm 5.57 \mathrm{mg} /$ day and $910.7 \pm 210.4 \mathrm{mg} /$ day respectively, whereas the mean intake of vitamin $A$, thiamine, riboflavin, niacin, vitamin $C$ and folic acid were $608.4 \pm 161.2 \mu \mathrm{g}, 1.2 \pm 0.2 \mathrm{mg}$, $1.6 \pm 0.2 \mathrm{mg}, 11.9 \pm 2.1 \mathrm{mg}, 113.3 \pm 2.1 \mathrm{mg}$ and $196.2 \pm 38.4 \mu \mathrm{g}$ respectively. Nutritional deficiency during pregnancy was positively related with low birth weight. Conclusion: In the rural setup of India majority of the pregnant women were having inadequate dietary intake. Hence, policies related to maternal nutrition should be made so as to decrease the prevalence of low birth weight.

Key words: Pregnant women, Third trimester, Dietary intake, Birth weight, Rural, India

\section{INTRODUCTION}

Nutritional deficiency during pregnancy in rural India is common. The nutritional requirements during pregnancy are increased and on the other hand the dietary intake decreases because of symptoms related to pregnancy. This adversely affects the weight of newborn. According to studies carried out in past, maternal nutrition and health are most important regulators of human foetal growth. If women are inadequately nourished, they are more likely to give birth to weak babies, thereby resulting in high infant mortality. ${ }^{1}$ Maternal nutrition is an important factor responsible not only for health of baby, but also for the baby's long term growth. ${ }^{2}$ Therefore understanding maternal nutrition and foetal growth relationship is critical. ${ }^{3}$

In developing countries low birth weight was major problem. According to WHO low birth weight define as birth weight less than $2.5 \mathrm{~kg}$. Prevalence of Low birth weight in India since independence has not shown any significant decline, it remains high at 28.0 percent, ${ }^{4}$ despite launching of successive interventional programmes by the Government of India for reducing the problem.

Address for Correspondence:

Krishna Kumar Sahu, Assistant Professor, Department of Community Medicine, Shrinivas Institute of Medical Sciences \& Research

Centre, Mukka, Surathkhal.

E-mail: krishnasahu74@gmail.com; Phone/Fax:+91-7783839833.

(C) Copyright AJMS 
Low birth weight leads to an impaired growth of the infant with its attendant risks of a higher mortality rate, increased morbidity, ${ }^{5}$ impaired mental development, ${ }^{6}$ and the risk of chronic adult disease. ${ }^{7}$ Nutritional deficiency is a modifiable risk factor for low birth weight. So this study concern to determine the nutritional status of pregnant women in third trimester of pregnancy and its effect on birth weight of newborn.

\section{MATERIALS AND METHODS}

This cross section descriptive type of study was conducted in Sarojni Nagar, primary health centre, Lucknow, Uttar Pradesh. It was a community based descriptive study. The sample size was based on the prevalence of low birth weight in India which was $28 \% .{ }^{4}$ Based on this assumption, sample size came out to be 323 with relative precision of $20 \%$ and design effect of 1.25 . A total of 323 pregnant women were registered in the present study. Out of the total registered pregnant women, 32 pregnant could not be followed up to the time of delivery. These women might had delivered at some other hospitals/health facilities or opted for home delivery. A total 291 pregnant women could be followed till the time of delivery. Out of these 291 deliveries, 287 were live births and four were still birth. The sample collection was started in October 2011 and it was completed in May 2012.

All the selected pregnant women were interviewed on predesigned schedule. At the time of registration in the study their biosocial correlates, obstetric history, anthropometric measurement, clinical examination, laboratory examination and dietary intake were recorded. Each subject was questioned in detail about her dietary intake on the basis of 24-h dietary recall method for the previous day. The consumption of daily diet was calculated in terms of the following food groups (in grams) cereals, pulses, meat/fish poultry, green leafy vegetables, fruits, milk, oil and sugar. The daily intake of calories (Kcal), proteins $(\mathrm{g})$, calcium $(\mathrm{mg})$, iron $(\mathrm{mg})$ and vitamins was calculated and compared with Recommended Dietary Allowance (RDA) tables provided by the Indian Council of Medical Research $(\mathrm{ICMR})^{8}$. The birth weight was measured immediate after delivery. In 287 newborn, 82 were low birth weight (LBW) and 205 were normal birth weight $(\mathrm{NBW})$.

Data was tabulated on Microsoft Excel Sheet and analyzed by using the software SPSS, version 17.0. Frequency distributions were calculated for all variables. One way ANOVA test was used for the comparing mean birth weight of babies. Univariate and multivariate analyses were performed to determine the influence of the dietary intake on the birth weight of a newborn. P values less than 0.05 were considered significant.

\section{RESULTS}

In the present study more than half $(53.6 \%)$ of the pregnant women belonged to 20-24 years and majority $(91.6 \%)$ were Hindus. 48.3 percent belonged to backward caste and a total, 59.1 percent of the study population were of IV socio-economic class.

Mean dietary intake of, cereals, pulses, GLV, root/tubers, oil \& fat, milk \& its products and sugar/jaggery were 344.0gms, $80.7 \mathrm{gms}, 81.7 \mathrm{gms}, 122.5 \mathrm{gms}, 24.8 \mathrm{gms}, 191.1 \mathrm{gms}$ and 20.0 gms respectively, in third trimester of pregnancy (Table-1).

In the current study mean energy, protein, iron and calcium intake during pregnancy were $2013.3 \pm 327.6 \mathrm{kcal} /$ day, $57.8 \pm 11.4 \mathrm{gm} /$ day, $30.15 \pm 5.57 \mathrm{mg} /$ day and $910.7 \pm$ $210.4 \mathrm{mg} /$ day respectively, whereas the mean intake of vitamin $A$, thiamine, riboflavin, niacin, vitamin $C$ and folic acid were $608.4 \pm 161.2 \mu \mathrm{gm} /$ day, $1.2 \pm 0.2 \mathrm{mg} /$ day, $1.6 \pm 0.2 \mathrm{mg} /$ day, $11.9 \pm 2.1 \mathrm{mg} /$ day, $113.3 \pm 2.1 \mathrm{mg} /$ day and $196.2 \pm 38.4 \mu \mathrm{gm} /$ day respectively (Table-2).

\begin{tabular}{|c|c|c|c|}
\hline Food item & $\begin{array}{c}\text { Mean intake } \\
\text { during third } \\
\text { trimester (gm) }\end{array}$ & $\begin{array}{l}\text { RDA in } \\
\text { pregnancy } \\
\text { (gm) }\end{array}$ & $\begin{array}{c}\text { Percentage } \\
\text { adequacy } \\
\text { intake }\end{array}$ \\
\hline Cereals & 344.0 & 445 & 77.3 \\
\hline Pulses & 80.7 & 55 & 146.4 \\
\hline $\begin{array}{l}\text { Green leafy } \\
\text { vegetables (GLV) }\end{array}$ & 81.7 & 100 & 81.7 \\
\hline $\begin{array}{l}\text { Root/tubers \& } \\
\text { other veg. }\end{array}$ & 100.0 & 100 & 100.0 \\
\hline Fruits & 25.0 & - & - \\
\hline Oil \& fat & 24.8 & 20 & 124.0 \\
\hline Milk \& milk product & 191.1 & 200 & 95.6 \\
\hline Sugar \& jaggery & 20.0 & 35 & 57.1 \\
\hline
\end{tabular}

\begin{tabular}{|c|c|c|c|}
\hline \multirow[t]{2}{*}{ Nutrient intake } & \multicolumn{3}{|c|}{ During third trimester of pregnancy } \\
\hline & Mean $\pm 2 S D$ & RDA & $\begin{array}{l}\text { Percent adequacy } \\
\text { of intake }\end{array}$ \\
\hline Calories (kcal/day) & $2013.3 \pm 327.6$ & 2250.0 & 89.5 \\
\hline Protein (gm/day) & $57.8 \pm 11.4$ & 78.0 & 74.1 \\
\hline Iron (mg/day) & $30.15 \pm 5.57$ & 35.0 & 86.1 \\
\hline Calcium (mg/day) & $910.7 \pm 210.4$ & 1200.0 & 75.9 \\
\hline Vitamin A ( $\mu \mathrm{gm} /$ day) & $608.4 \pm 161.2$ & 800.0 & 76.1 \\
\hline Thiamine (mg/day) & $1.2 \pm 0.2$ & 1.2 & 100.0 \\
\hline Riboflavin (mg/day) & $1.6 \pm 0.2$ & 1.4 & 114.3 \\
\hline Niacin (mg/day) & $11.9 \pm 2.1$ & 14.0 & 85.0 \\
\hline Vitamin C (mg/day) & $113.3 \pm 2.1$ & 60.0 & 188.8 \\
\hline Folic acid ( $\mu \mathrm{gm} / \mathrm{day})$ & $196.2 \pm 38.4$ & 400.0 & 49.1 \\
\hline
\end{tabular}


In anthropometric measurements, mean weight of pregnant women with LBW and NBW was $48.7 \pm 6.2 \mathrm{~kg}$ and $50.7 \pm 7.2 \mathrm{~kg}$ respectively, which was significantly associated with LBW. In lab investigation, haemoglobin level of mother during third trimester was significantly related with LBW. Mean haemoglobin level of LBW mothers was 9.6 \pm 1.4 $\mathrm{gm} \%$. In dietary intake of energy, protein, iron, calcium, vitamin $\mathrm{A}$, vitamin $\mathrm{B} 1$, vitamin $\mathrm{B} 2$, vitamin $\mathrm{B} 5$, vitamin $\mathrm{C}$ and folic acid were significantly related with LBW (Table-3).

In multilogistic regression energy, riboflavin, folic acid and vitamin C had significant effect on birth weight. Pregnant women consuming energy less than 2025 calories (deficient $>10 \%$ of $\mathrm{RDA}$ ) were 2.918 time more prone to deliver LBW. Inadequate riboflavin, folic acid and vitamin C intake during pregnancy were associated with higher risk of LBW

\begin{tabular}{|c|c|c|c|}
\hline Parameters & $\begin{array}{c}\text { LBW }(n=82) \\
\text { mean } \pm S D\end{array}$ & $\begin{array}{c}\text { NBW }(n=205) \\
\text { mean } \pm S D\end{array}$ & $\begin{array}{c}\text { t-test } \\
\text { p value }\end{array}$ \\
\hline $\begin{array}{l}\text { Weight at third } \\
\text { trimester }(\mathrm{kg})\end{array}$ & $48.7 \pm 6.2$ & $50.7 \pm 7.2$ & 0.03 \\
\hline Height (cm) & $148.3 \pm 5.6$ & $149.0 \pm 5.8$ & 0.38 \\
\hline Haemoglobin (gm \%) & $9.6 \pm 1.4$ & $10.3 \pm 1.1$ & $<0.001$ \\
\hline Energy (kcal/day) & $1926.2 \pm 328.6$ & $2038.3 \pm 340.0$ & 0.02 \\
\hline Protein (gm/day) & $54.6 \pm 11.1$ & $58.8 \pm 11.8$ & 0.01 \\
\hline Iron (gm/day) & $26.9 \pm 5.3$ & $31.1 \pm 5.2$ & $<0.001$ \\
\hline Calcium (mg/day) & $858.8 \pm 245.0$ & $932.0 \pm 192.5$ & 0.01 \\
\hline Vitamin A ( $\mu \mathrm{gm} /$ day) & $541.1 \pm 174.3$ & $636.0 \pm 148.7$ & $<0.001$ \\
\hline Thiamine (mg/day) & $1.1 \pm 0.2$ & $1.3 \pm 0.2$ & $<0.001$ \\
\hline Riboflavin (mg/day) & $1.5 \pm 0.3$ & $1.7 \pm 0.2$ & $<0.001$ \\
\hline Niacin (mg/day) & $10.5 \pm 1.6$ & $12.3 \pm 2.0$ & $<0.001$ \\
\hline Vitamin C (mg/day) & $83.1 \pm 26.9$ & $127.5 \pm 26.5$ & $<0.001$ \\
\hline Folic acid ( $\mu \mathrm{gm} /$ day) & $165.1 \pm 40.3$ & $208.2 \pm 30.6$ & $<0.001$ \\
\hline
\end{tabular}

\begin{tabular}{|c|c|c|c|c|}
\hline Nutrients & & B coefficient & *aPR (Cl) & $P$ value \\
\hline Energy & $\geq 2025$ & & 1 & \\
\hline$(\mathrm{kcal} / \mathrm{d})$ & $<2025$ & 0.984 & $2.676(1.230-5.822)$ & 0.01 \\
\hline Protein & $\geq 70.2$ & & 1 & \\
\hline$(\mathrm{gm} / \mathrm{d})$ & $<70.2$ & 0.810 & $2.249(0.718-7.045)$ & 0.22 \\
\hline Iron & $\geq 31.5$ & & 1 & \\
\hline$(\mathrm{mg} / \mathrm{d})$ & $<31.5$ & 0.126 & $1.134(0.534-2.407)$ & 0.88 \\
\hline Calcium & $\geq 1080$ & & 1 & \\
\hline$(\mathrm{mg} / \mathrm{d})$ & $<1080$ & 0.237 & $1.267(0.516-3.113)$ & 0.61 \\
\hline Vitamin A & $\geq 720$ & & 1 & \\
\hline$(\mu \mathrm{g} / \mathrm{d})$ & $<720$ & 0.543 & $1.722(0.711-4.168)$ & 0.23 \\
\hline Thiamine & $\geq 1.08$ & & 1 & \\
\hline$(\mathrm{mg} / \mathrm{d})$ & $<1.08$ & 0.637 & $1.890(0.872-4.095)$ & 0.11 \\
\hline Riboflavin & $\geq 1.26$ & & 1 & \\
\hline$(\mathrm{mg} / \mathrm{d})$ & $<1.26$ & 2.714 & $15.095(5.531-41.196)$ & $<0.001$ \\
\hline Folic acid & $\geq 200$ & & 1 & \\
\hline$(\mu \mathrm{g} / \mathrm{d})$ & $<200$ & 2.103 & $8.190(3.271-20.505)$ & $<0.001$ \\
\hline Vitamin C & $>54$ & & 1 & \\
\hline$(\mathrm{mg} / \mathrm{d})$ & $\leq 54$ & 2.207 & $9.092(0.985-83.967)$ & 0.05 \\
\hline
\end{tabular}

with an adjusted prevalence ratio $(\mathrm{aPR})=15.095,8.190$ and 9.092 respectively (Table-4).

\section{DISCUSSION}

In present study in nutrient intake, only thiamine, riboflavin and vitamin $\mathrm{C}$ were consumed in adequate amount by pregnant women during third trimester of pregnancy. Intake of energy, protein, iron, calcium, vitamin A, thiamine and folic acid were low with reference to ICMR recommendation (National Institute of Nutrition, 2009). A study of rural Orissa showed that only the intake of vitamins like vitamin $\mathrm{C}$, niacin, and thiamine were satisfactory in third trimester of pregnancy. This indicates that the diet of pregnant women was not adequate to meet the requirements of nutrients during the course of pregnancy. ${ }^{1}$ The finding of this study was also similar with other study in urban and rural India. The result of these studies was that consumption of energy and nutrient during pregnancy were inadequate as compared to recommended RDA.., 10

Pregnant women who delivered LBW babies were significantly low in weight and hemoglobin level than women who delivered normal birth weight babies. It was also observed that pregnant women who delivered NBW were consumed significantly higher amount of energy, protein, iron, calcium, vitamin $A$, vitamin $B$ complex and vitamin $C$ than those who delivered LBW babies. Similar results are seen in different studies. ${ }^{2,9,11}$

In current study, inadequate micronutrient intake like riboflavin, vitamin $\mathrm{C}$ and folic acid were significantly associated with low birth weight babies. Ramkrishnan et al in his Meta analysis found similar association between vitamin $\mathrm{C}$ consumed by pregnant mothers and LBW babies. ${ }^{12}$ De Onis et al also showed that folate supplementation reduces the risk of IUGR (OR $0.60,95 \%$ CI $0.37,0.97) .{ }^{13}$ Similarly Scholl et al, reported that low folate intake $(<240 \mu \mathrm{g} / \mathrm{d})$ increases three fold risk for low birth weight. ${ }^{14}$

\section{CONCLUSION}

In rural India majority of pregnant women were consuming inadequate amount of nutrition. Insufficient macronutrients and micronutrients intake especially during third trimester of pregnancy were associated with low birth weight. So the current maternal and child health $(\mathrm{MCH})$ programmes should focus not only on energy supplementations but also on importance of micronutrients in prevention of LBW.

\section{Ethical clearance}

The study protocol was submitted to the institutional ethical committee and clearance was obtained. 


\section{REFERENCES}

1. Sahoo S and Panda B. A study of nutritional status of pregnant women of some villages in Balasore districts, Orissa. J Hum Ecol 2006; 20:227-232.

2. Jackson AA and Robinson SM. Dietary guideline for pregnancy. Public Health Nutr 2001; 10:623-630.

3. Rao BT, Aggarwal $A K$ and Kumar R. Dietary intake in third trimester of pregnancy and prevalence of LBW: A communitybased study in a rural area of Haryana. Ind J Com Med 2007; 32:272-276.

4. WHO and UNICEF. Low birth weight: Country, regional and global estimates, Geneva: World Health Organization. 2011.

5. Ashworth A. Effects of intrauterine growth retardation on mortality and morbidity in infants and young children. J Clin Eur Nutr 1998; 52(Suppl 1):S34-S42.

6. Grantham-McGregor SM. Small for gestational age, term babies, in the first six years of life. Eur J Clin Nutr 1998; 52(Suppl 1):S59-S64.

7. Barker DJP. Mothers, babies and health in later life. Edinburgh: Churchill Livingstone. 1998.
8. ICMR. Nutrient requirement and recommend dietary allowances for Indians, A Report of expert group of ICMR. 2010.

9. Khoushabi F and Saraswathi G. Association between Maternal Nutrition Status and Birth Weight of Neonates in Selected Hospitals in Mysore City, India. Pakistan Journal of Nutrition 2010; 9(12):1124-1130.

10. Kharade PP and Antony U. Nutrition status and outcome of pregnancy in young and older mothers in Mumbai. Ind $\mathrm{J}$ Nutr Diete 2002; 139:26-30.

11. Snihareni D and Lakshmi UK. Effect of supplementation of cynodon dactylon (Arugampul) juice/powder on anaemic pregnant women. Ind J Nutr Diete 2001; 38:281-291.

12. Ramkrishnan U, Manjrekar R, Rivera J, Gonzales-Cossio T and Martorell R. Micronutrients and pregnancy outcome: A review of the literature. Nutr Res 1999; 19:103-159.

13. De Onis M and Villar J, Gulmezoglu M. Nutritional interventions to prevent intrauterine growth retardation: Evidence from randomized controlled trials. Eur J Clin Nutr 1998; 52:S83-S93.

14. Scholl TO, Hediger ML, Schall JI, Khoo CS and Fischer RL. Dietary \& serum folate: their influence on the outcome of pregnancy. Am J Clin Nutr 1996; 63:520-525.

\section{Authors Contribution:}

KKS, MZI- designed the study, analysed the data, drafted the manuscript, \& reviewed the manuscript; MA, SKS - Contributed to the study design; MM - Reviewed the manuscript.

Source of Support: University of Peradeniya Research Grants RG/2011/27/M and RG/2012/CG-1/38/M, Conflict of Interest: None declared. 